\title{
Detection and Mapping of Actor Linkages in Women led Agricultural Innovation System (AIS)
}

\author{
Rema Das* \\ Department of Agricultural Extension, Rabindra Nath Tagore Agriculture College, Deoghar, \\ BAU, Kanke, Ranchi, Jharkhand-814157, India \\ *Corresponding author
}

\begin{tabular}{|l|}
\hline Ke y w o r d s \\
Agricultural \\
innovation system, \\
$\begin{array}{l}\text { Actors, Actor } \\
\text { linkage map, Actor } \\
\text { linkage matrix, } \\
\text { Innovation, } \\
\text { Information }\end{array}$ \\
\hline Article Info \\
\hline $\begin{array}{l}\text { Accepted: } \\
\text { 22 June 2020 } \\
\text { Available Online: } \\
\text { 10 July 2020 }\end{array}$ \\
\hline
\end{tabular}

\section{A B S T R A C T}

Identification of the key actors is vital to trace out the drivers of change in an innovation system. Analysis of actor linkage looks at their needs, interest, objectives, power and relationships. The efficiency and capacity of an agricultural innovation system can be strengthened by creating strong linkage between researchers, educationists, extension agents, farmers and other stakeholders of the system. Agricultural interventions often fail because the actors are not given enough consideration. Hence, the present study aims to detect and map the actor linkages in an agricultural innovation system to envisage the role, relationship and interactions among the actors of change. The present study was conducted at Cooch Behar district of West Bengal, India. Total hundred respondents were randomly selected for the study that is comprised of farmers, input dealers, NGO staff, Bank employees, KVK staff, farmer's club members, SAU, panchayat members, private companies and state extension professionals etc. The personal interview method is followed to collect the information from each and every women stakeholder of the women led agricultural innovation system in the study area.Actor oriented tools like Actor Linkage Map and Actor linkage Matrix were used in this study. Actor linkage map reflects that farmers have strong linkage with the NGO and input dealers of the local area while they have weak link with the State Agricultural University and Krishi Vigyan Kendra at district level. Private companies have no direct link with the farmers in the system. Farmer's club also has strong communication with the NGO and input dealers. The map also revealed that gram panchayat as a political institution has no such effective linkage in the system in terms of sharing information or taking part in extension activities. KVK, NGO, farmer's club are mainly involved in dissemination of information, trainings to others in the system. 


\section{Introduction}

An innovation will only become fruitful when the end users are ready to accept the change and adopt it on a continuous basis. We know that diffusion of innovation occurs through transfer of technologies from its point of creation to its ultimate users. This indicates effective communication link in agriculture and development is vital to uplift the status of rural poor by putting research into use. Such links are useful to recommend technologies and management practices to be fitted to local ecological conditions and in the modification of existing farming system and in initiating further research.

So, focusing only on farmers and extension agents interface will not bring out coherent innovations because many other actors (e.g. university staff from different disciplines, applied researchers, political institutions, development departments, financial institutions, private companies, farmers association, policy-makers, agroindustry, etc.) play crucial role in bringing out such innovations. Innovations could only be expected to emerge when the multiple actors (including farmers), who could influence the bringing about of adequate knowledge and technology, co-operate to improve collective performance (Leeuwis and Van den Ban 2004).

Identification of the key actors is vital to trace out the factors triggering change in an innovation system. Actors are all those people who have a stake (or share) in a particular issue or system. Stakeholders can be groups of people, organizations, institutions and sometimes even individuals. Actor analysis is a way of conceptualizing a system through its actors. It looks at their needs, interest, objectives, power and relationships. Importance and influence are not the same. For example, rural women farmers might have been identified as an important actor for narrowing the gender gap, but they may have little influence in decision-making processes.

Spielman (2006) reported that actors that traditionally have not been included in the top-down approach to innovations process such as private sectors input dealers and NGOs have become important in the innovation process triggering demand for improved farming technologies. Klerkx and Leeuwis (2009) reported that "Innovation intermediaries" is a concept in innovation studies that assists with our understanding of the role of firms, agencies, and individuals that facilitate innovation by providing the bridging, brokering, knowledge transfer necessary to bring together the range of different organizations, and knowledge needed to create successful innovation. Therefore, the efficiency and capacity of an agricultural innovation system can be strengthened by creating strong linkage between researchers, educationists, extension agents, farmers and other stakeholders of the system. The concept of linkage implies the communication and working relationship established between two or more organisations pursuing commonly shared objectives in order to have regular contact and improved productivity (Agbamu, 2000). It is also defined as the coordinated channels for exchange or flows of technology, information and resources between organizations in an agricultural innovation system (Peterson, Gijsbers and Wilks, 2003). Agricultural linkage promotes successful generation, dissemination and consumption of information or services to accelerate learning, increase productivity, marketability of the produces, and improve the livelihoods of the stakeholders in a particular region. Involvement of all innovation actors in the information/ knowledge exchange, the use of farmers' indigenous knowledge and farming systems are crucial (Aflakpui, 2007) to 
enhance information transfer, technology adoption rate of farmers, and make genuine decision on agricultural investment. The linkage between the stakeholders helps in understanding the relationship between actors in an Innovation System and draws out the strong and weak links in the network (Mohammad et al., 2012).

Many of the research attempts carried out in the study area revealed that there is less adoption of new technologies among the farmers due to weak link between the stakeholders in agricultural system. In the study area NGO named Satmile Satish Club O Pathagar was partner of integrated model project implemented by the Block Development Office at village level that has targeted women self-help groups as their beneficiaries. The components of this project were plantation of guava and lemon plants, production of onion, setting up of polyhouse for production of capsicum, spinach, amaranthus and chilli and poultry rearing. In this project NGO has provided training to the women SHG members on modern agricultural practices and poultry rearing with the help of scientists from the State Agricultural University. Other stakeholders like input dealers, private companies, financial institutions, Department of Agriculture at Block level were also involved in this project. However, Agricultural interventions often fails because the actors are not given due consideration. Keeping this in mind, the present study attempts to identify and map the actor linkages in women led agricultural innovation system to envisage the role, relationship and interactions among the actors of change.

Actor oriented tools like Actor Linkage Map and Actor Linkage Matrix were used in this study. The results revealed the collective action of various actors in terms of strong, medium and weak linkages among them.

\section{Materials and Methods}

\section{Study area}

The present study was conducted at Cooch Behar district of West Bengal. West Bengal is one of the 29 States in India. West Bengal is bounded by Nepal in the north, Assam in the north east, Republic of Bangladesh in the east, Bay of Bengal in the south, Orissa in the south east and Jharkhand in the north east. Cooch Behar is a northern district of West Bengal. It is surrounded by the district Jalpaiguri, Assam and Republic of Bangladesh. This district contains 12 blocks 128 Gram panchayats and 1188 villages. The main river is Teesta and the main crops are rice, wheat, jute and mustard. This district is familiar in vegetables and fruit production through the year. The total area of Cooch Behar is 3, 31,566 ha. In this district the total cultivation no. is 290047 (male 259458 and female-30589) and the no. of marginal cultivator is 71217 (male-17369 and female53848).The climate is highly humid throughout the year. Wheat is one of the most important cereal crops in Rabi season; Pulse is another important crop.

\section{Selection of respondents}

The district Cooch Behar has been selected purposively. The Cooch Behar block-I from the chosen district was selected with the help of simple random sampling. Then from the selected block two gram panchayat namely Falimari and Chilkirhat were selected randomly. From each gram panchayat fifty women actors were randomly selected with the support of local NGO and in consultation with the Department of Agriculture. Total hundred respondents were randomly selected for the study that is comprised of farmers, input dealers, NGO staff, Bank employees, KVK staff, farmer's club members, SAU, panchayat members, private companies and state extension professionals etc. 


\section{Collection of data}

The personal interview method is followed to collect the information from each and every women stakeholder of the women led agricultural innovation system in the study area. In course of this survey informal discussion was carried out with some farm women, local leader, farmer's club, NGOs, input dealers, service providers and extension personnel etc.of the locality that are associated with agricultural developmentto obtain information regarding the actors, their role, activities within the innovation system.

\section{Methods used}

The present study used some methodologies for mapping linkage between these actors such as actor linkage map and actor linkage matrix that are identified by Biggs and Matsaert (2004). In actor linkage map the key actors are shown on the map with arrows between them indicating flows of information. In an actor linkage analysis there is always an arm going in each direction. The intensity of these flows can be illustrated by the width of the arrows. Actor linkage matrix identifies all the actors and shows the links between major actors in an innovation system.

The matrix is represented by listing actors along the vertical and horizontal axes. The cells in the matrix represent flows of information from the actors in the rows to actors in the columns. In the matrix all cells can be identified by their co-coordinators.

The matrix basically plots the same information as the map, but has additional advantages such as: it deals with more complex situations and more actors, it has a cell for every possible linkage and so encourages one to explore all possibilities, it enables users to quantify the strength of linkages such as s (strong), m (medium), w (weak) etc.

\section{Results and Discussion}

Fig.1-represents the schematic diagram of the women led agricultural innovation system at block level in the study area.

Fig.2 presents the actor linkage map of the women led agricultural innovation system in the study area. In this map linkages among the stakeholders of the system is expressed as strong, medium and weak based on actor's perception about the transparency, credibility, complexity, intensity of collaboration, rules and regulations in their functioning as a part of the system.

Table-1 represents the actor linkage matrix of the women led agricultural innovation system in the study area. It is used to present actor linkages in a different way. It indicates each actor's role and their involvement in the system.

\section{Actor Linkage Map}

The linkage of each actor with the other actors of the system is described below as per the actor linkage map.

\section{Farm women}

Farm women have strong linkage with input dealers as they are the local agents of supplying inputs. Farm women mostly seek information from the input dealers as they are timely available and within their reach. Moreover, since input dealers are already familiar to their male counterparts and their husbands also goes to them for agricultural information, so women also consider input dealers as trustworthy and reliable source of information. Farm women also share strong linkage with the local NGO and seek advice regarding modern agricultural practices, availability of inputs and machineries and how to make profit from the farm. 
Table.1 Actor linkage matrix of an agricultural innovation system

\begin{tabular}{|c|c|c|c|c|c|c|c|c|}
\hline Actors & Researchers & Extensionists & Farmers & $\begin{array}{l}\text { Farmer's } \\
\text { Club }\end{array}$ & $\begin{array}{l}\text { Input } \\
\text { Dealers }\end{array}$ & NGO & $\begin{array}{l}\text { Financial } \\
\text { Institutions }\end{array}$ & $\begin{array}{l}\text { Private } \\
\text { Companies }\end{array}$ \\
\hline Researchers & & $\begin{array}{l}\text { Dissemination } \\
\text { of research } \\
\text { outcome, } \\
\text { provide } \\
\text { farmer's } \\
\text { feedback to the } \\
\text { researcher. }\end{array}$ & $\begin{array}{l}\text { Identification } \\
\text { of field } \\
\text { problems \& } \\
\text { participation } \\
\text { in research } \\
\text { work with } \\
\text { other actors. }\end{array}$ & $\begin{array}{l}\text { Trial, } \\
\text { application, } \\
\text { diffusion of } \\
\text { research } \\
\text { outputs } \\
\text { among } \\
\text { farmers }\end{array}$ & $\begin{array}{l}\text { Sharing } \\
\text { knowledge of } \\
\text { quality and } \\
\text { quantity } \\
\text { required for } \\
\text { input } \\
\text { generation. }\end{array}$ & $\begin{array}{l}\text { Link between } \\
\text { researcher and } \\
\text { beneficiaries, } \\
\text { partner for } \\
\text { need-based } \\
\text { research } \\
\text { programme }\end{array}$ & $\begin{array}{l}\text { Meet financial } \\
\text { requirements } \\
\text { for research } \\
\text { projects }\end{array}$ & $\begin{array}{l}\text { Active partner } \\
\text { for generation } \\
\text { of new } \\
\text { technologies, } \\
\text { funding in } \\
\text { research }\end{array}$ \\
\hline Extensionists & $\begin{array}{l}\text { Generation, } \\
\text { testing and } \\
\text { validation of } \\
\text { location- } \\
\text { specific and } \\
\text { input intensive } \\
\text { technologies. }\end{array}$ & & $\begin{array}{l}\text { Express their } \\
\text { needs and } \\
\text { interests, } \\
\text { participate in } \\
\text { preparation } \\
\text { of action } \\
\text { plan. }\end{array}$ & $\begin{array}{l}\text { Skill } \\
\text { upgradation, } \\
\text { consultancy } \\
\text { and guidance. }\end{array}$ & $\begin{array}{l}\text { Distribution } \\
\text { and } \\
\text { promotion of } \\
\text { quality } \\
\text { inputs. }\end{array}$ & $\begin{array}{l}\text { Disseminating } \\
\text { knowledge, } \\
\text { mobilizing } \\
\text { farmers into } \\
\text { groups and } \\
\text { conducting } \\
\text { meetings, field } \\
\text { visits }\end{array}$ & $\begin{array}{l}\text { Financial } \\
\text { assistance for } \\
\text { projects, on- } \\
\text { farm trials, } \\
\text { front-line } \\
\text { demonstrations, } \\
\text { organizing } \\
\text { Farmer's Fair }\end{array}$ & $\begin{array}{l}\text { Promotion of } \\
\text { latest } \\
\text { technologies }\end{array}$ \\
\hline Farmers & $\begin{array}{l}\text { Develop HYVs } \\
\text { seeds, planting } \\
\text { material, } \\
\text { improved } \\
\text { livestock } \\
\text { breeds. }\end{array}$ & $\begin{array}{l}\text { Diagnostic and } \\
\text { advisory } \\
\text { services, input } \\
\text { supply, field } \\
\text { demonstration, } \\
\text { training, } \\
\text { Farmer's fair, }\end{array}$ & & $\begin{array}{l}\text { Impart } \\
\text { training to } \\
\text { SHGs, input } \\
\text { supply, } \\
\text { awareness on } \\
\text { modern } \\
\text { practices, link } \\
\text { farmers with } \\
\text { market }\end{array}$ & $\begin{array}{l}\text { Supply of } \\
\text { improved } \\
\text { agricultural } \\
\text { Inputs, } \\
\text { Advisory } \\
\text { services. }\end{array}$ & $\begin{array}{l}\text { Disseminating } \\
\text { knowledge, } \\
\text { awareness } \\
\text { programs, } \\
\text { training, } \\
\text { diagnostic and } \\
\text { advisory } \\
\text { services }\end{array}$ & $\begin{array}{l}\text { provide loans, } \\
\text { knowledge in } \\
\text { banking } \\
\text { operation, loan } \\
\text { recovery, crop } \\
\text { insurance } \\
\text { schemes, issue } \\
\text { of Kisan Credit } \\
\text { Card etc. }\end{array}$ & $\begin{array}{l}\text { Agricultural } \\
\text { input } \\
\text { provision }\end{array}$ \\
\hline $\begin{array}{l}\text { Farmer's } \\
\text { Club (FC) }\end{array}$ & $\begin{array}{l}\text { Developing } \\
\text { quality seeds } \\
\text { and other } \\
\text { inputs }\end{array}$ & $\begin{array}{l}\text { Information } \\
\text { sharing, } \\
\text { capacity } \\
\text { building, } \\
\text { organizing FFS } \\
\text { \& exposure } \\
\text { visit. }\end{array}$ & $\begin{array}{l}\text { Share } \\
\text { experience } \\
\text { with other } \\
\text { farmers, } \\
\text { participate in } \\
\text { training } \\
\text { programmes. }\end{array}$ & & $\begin{array}{l}\text { Supply of } \\
\text { inputs at } \\
\text { desired } \\
\text { quality and } \\
\text { quantity. }\end{array}$ & $\begin{array}{l}\text { Formation and } \\
\text { nurturing, } \\
\text { capacity } \\
\text { building }\end{array}$ & $\begin{array}{l}\text { Credit } \\
\text { facilities, act as } \\
\text { representative } \\
\text { of banks to } \\
\text { other farmers. }\end{array}$ & $\begin{array}{l}\text { Distribution of } \\
\text { agricultural } \\
\text { inputs }\end{array}$ \\
\hline $\begin{array}{l}\text { Input } \\
\text { Dealers }\end{array}$ & $\begin{array}{l}\text { Production of } \\
\text { inputs at } \\
\text { desired quality } \\
\text { and quantity. }\end{array}$ & $\begin{array}{l}\text { Arranges } \\
\text { training to } \\
\text { update } \\
\text { knowledge and } \\
\text { skill of dealers. }\end{array}$ & $\begin{array}{l}\text { Share their } \\
\text { problems and } \\
\text { concerns. }\end{array}$ & $\begin{array}{l}\text { Purchase of } \\
\text { bulk inputs, } \\
\text { distribution } \\
\& \text { sale of } \\
\text { inputs. }\end{array}$ & & $\begin{array}{l}\text { Identification } \\
\text { of sources of } \\
\text { input supply }\end{array}$ & $\begin{array}{l}\text { Avail credit for } \\
\text { purchasing } \\
\text { inputs and } \\
\text { machineries }\end{array}$ & $\begin{array}{l}\text { Distribution, } \\
\text { marketing and } \\
\text { sale of } \\
\text { agricultural } \\
\text { Inputs. }\end{array}$ \\
\hline NGO & $\begin{array}{l}\text { Field trial of } \\
\text { newly } \\
\text { developed } \\
\text { technologies, } \\
\text { Implementation } \\
\text { of research } \\
\text { programmes. }\end{array}$ & $\begin{array}{l}\text { Selection of } \\
\text { progressive } \\
\text { farmers, } \\
\text { training of } \\
\text { SHGs. }\end{array}$ & $\begin{array}{l}\text { Raising } \\
\text { issues to be } \\
\text { solved, } \\
\text { participate in } \\
\text { trainings }\end{array}$ & $\begin{array}{l}\text { Seek } \\
\text { guidance for } \\
\text { managing } \\
\text { and smooth } \\
\text { functioning }\end{array}$ & $\begin{array}{l}\text { Capacity } \\
\text { enhancement, } \\
\text { provide } \\
\text { platform to } \\
\text { link with } \\
\text { other actors. }\end{array}$ & & $\begin{array}{l}\text { Funding } \\
\text { training } \\
\text { programmes } \\
\text { for farmers, } \\
\text { funding linkage } \\
\text { platforms }\end{array}$ & $\begin{array}{l}\text { Promotion, } \\
\text { demonstration, } \\
\text { marketing, } \\
\text { selling, and } \\
\text { maintenance } \\
\text { of machineries }\end{array}$ \\
\hline $\begin{array}{l}\text { Financial } \\
\text { Institutions }\end{array}$ & $\begin{array}{l}\text { Avail financial } \\
\text { support to carry } \\
\text { out research }\end{array}$ & $\begin{array}{l}\text { Financial } \\
\text { assistance for } \\
\text { projects, on- } \\
\text { farm trials. }\end{array}$ & $\begin{array}{l}\text { Avail loans, } \\
\text { acquire } \\
\text { knowledge in } \\
\text { banking } \\
\text { operation, loan } \\
\text { recovery. }\end{array}$ & $\begin{array}{l}\text { Financial } \\
\text { support, act } \\
\text { as } \\
\text { representative } \\
\text { of banks to } \\
\text { other farmers. }\end{array}$ & $\begin{array}{l}\text { Borrow } \\
\text { money to } \\
\text { purchase \& } \\
\text { sell inputs in } \\
\text { bulk. }\end{array}$ & $\begin{array}{l}\text { Financial } \\
\text { assistance, } \\
\text { promotion of } \\
\text { various } \\
\text { schemes }\end{array}$ & & $\begin{array}{l}\text { Avail capital, } \\
\text { loans }\end{array}$ \\
\hline $\begin{array}{l}\text { Private } \\
\text { Companies }\end{array}$ & $\begin{array}{l}\text { Provide } \\
\text { technical } \\
\text { expertise for } \\
\text { production of } \\
\text { quality inputs, } \\
\text { research on } \\
\text { agricultural } \\
\text { issues }\end{array}$ & $\begin{array}{l}\text { Promotion of } \\
\text { latest } \\
\text { technologies } \\
\text { and input } \\
\text { supply. }\end{array}$ & $\begin{array}{l}\text { Share } \\
\text { problems and } \\
\text { seek advice } \\
\text { to be } \\
\text { involved }\end{array}$ & $\begin{array}{l}\text { Purchasing } \\
\text { various } \\
\text { inputs }\end{array}$ & $\begin{array}{l}\text { Distribution, } \\
\text { marketing } \\
\text { and sale of } \\
\text { agricultural } \\
\text { Inputs. }\end{array}$ & $\begin{array}{l}\text { Promotion, } \\
\text { demonstration, } \\
\text { marketing, } \\
\text { selling, and } \\
\text { maintenance } \\
\text { of machineries }\end{array}$ & $\begin{array}{l}\text { Provide } \\
\text { working and } \\
\text { venture capital }\end{array}$ & \\
\hline
\end{tabular}


Fig.1 Identified women led Agricultural Innovation System (AIS) in the study area

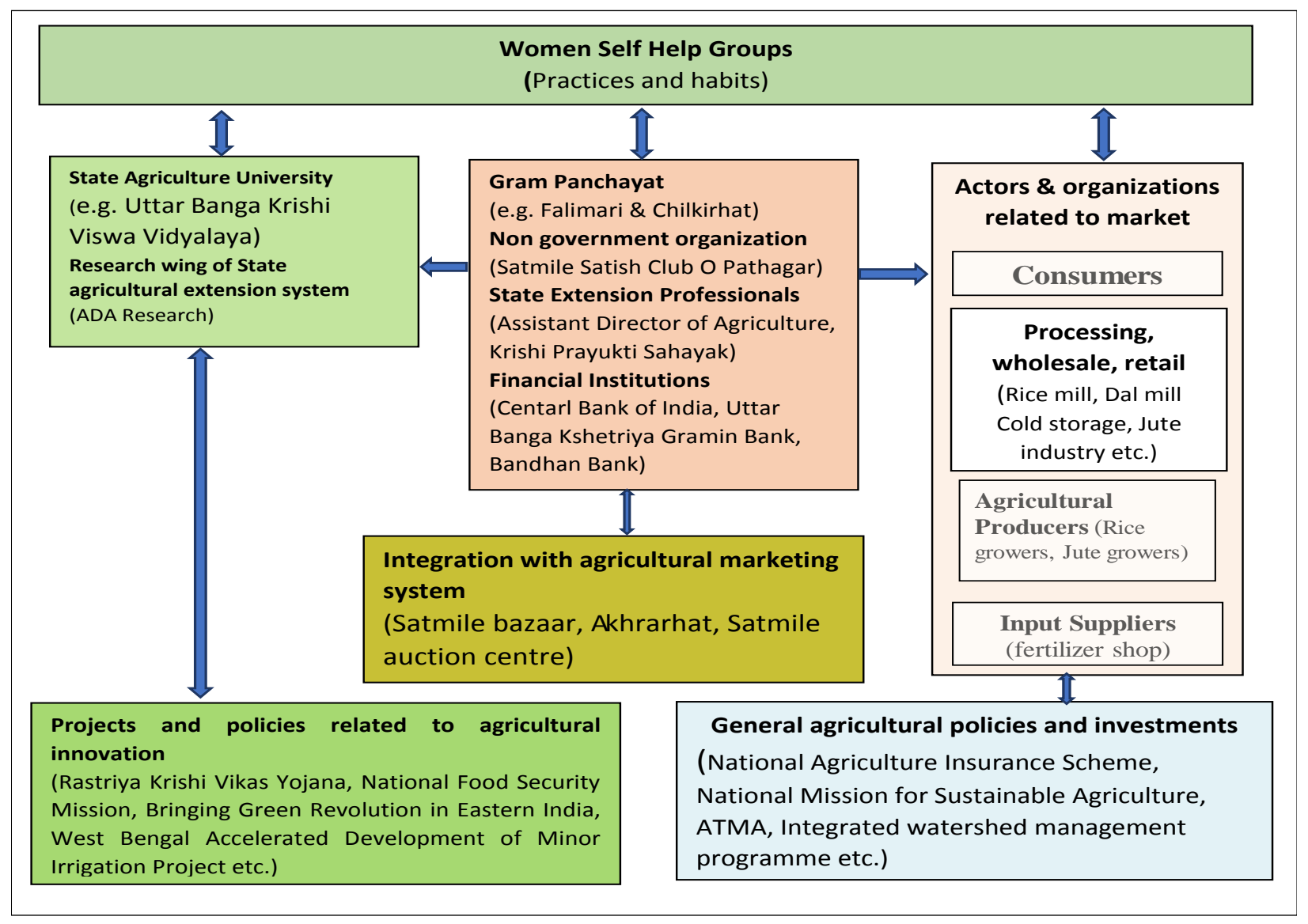

Fig.2: Actor Linkage Map of the Women led Agricultural Innovation System

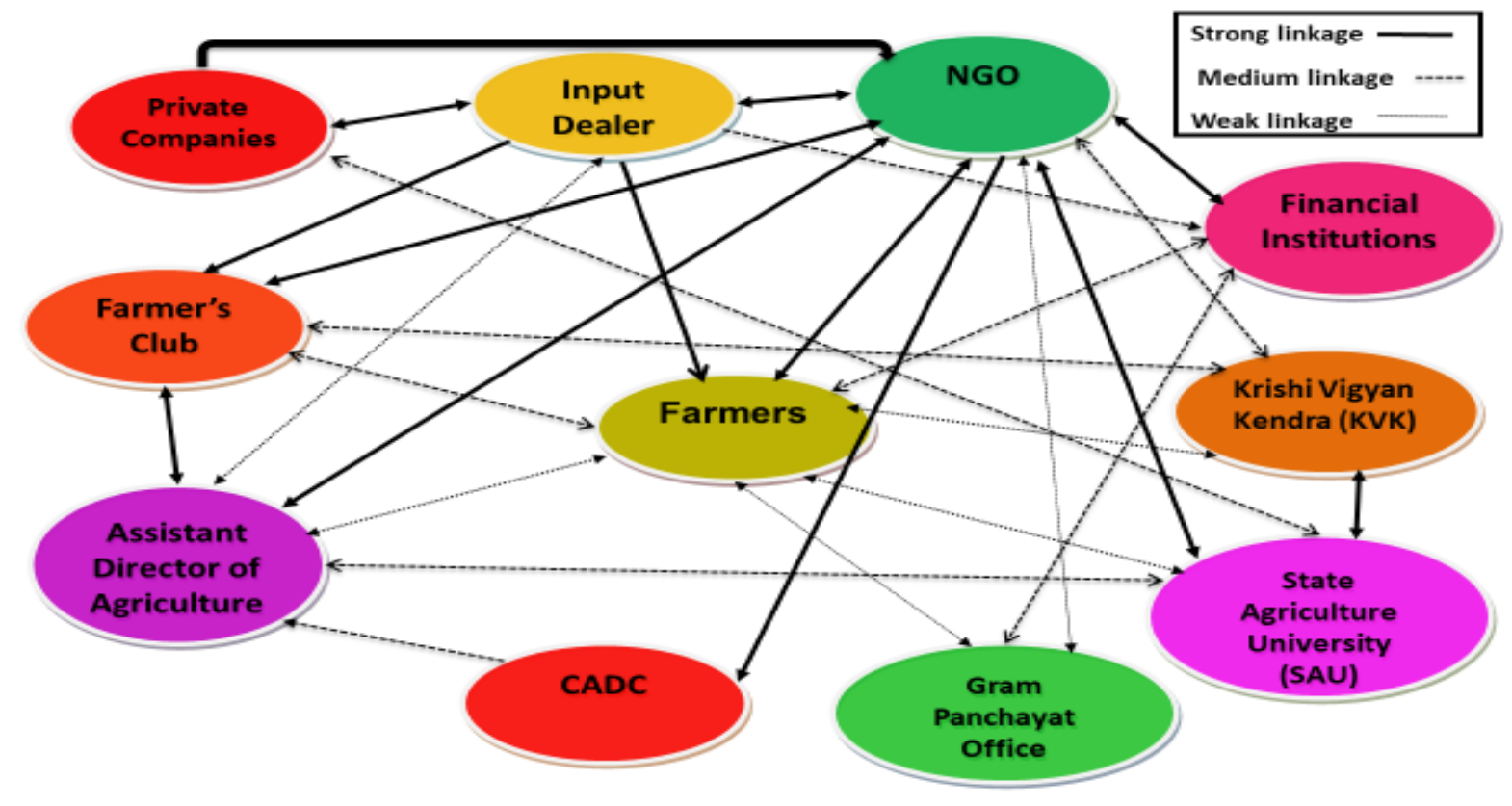




\section{Glimpses of actor's involvement in the innovation system}
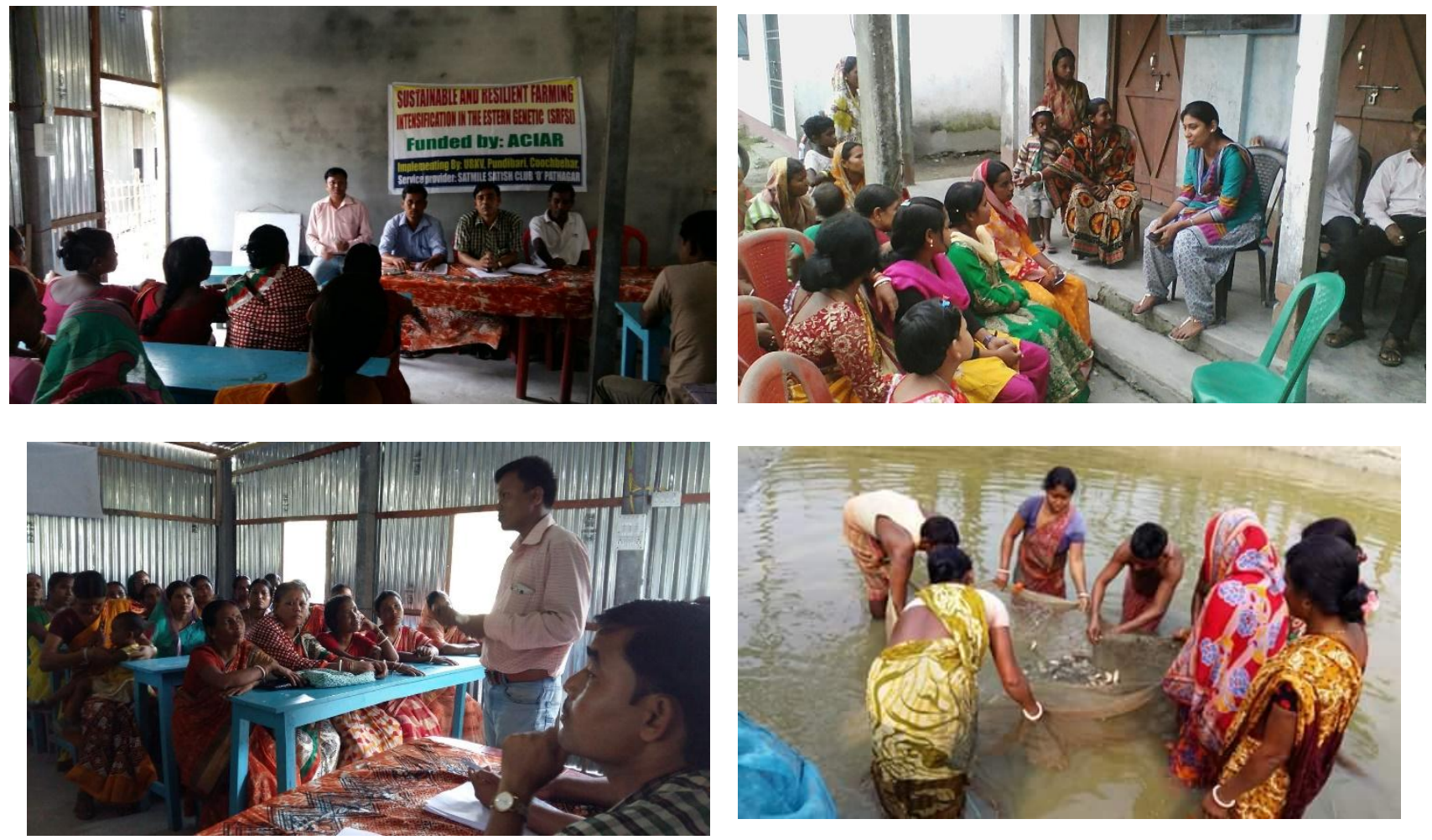

As farm women of this study are also the members of SHGs so most of the groups have their registration under this NGO. The NGO always contact with the office bearers of these SHGs regarding any women development programmes, workshops, training or demonstrations conducted in the study area. In this way, women are getting all government facilities through this NGO.

Usually farm women residing near farmers' club or having membership in the club access the services from the club otherwise they have not much acquainted with the functioning of farmers' club. Farm women have medium linkage with financial institutions as they often face problem in case of opening bank accounts, getting loans at right time and sometimes employees become less cooperative. Farm women are the job card holders who are engaged in 100 days work under MGNREGA Act do not get their payment timely. That is why farm women

perceive that gram panchayat officials are not working properly. Farm women has weak linkage with Assistant Director of Agriculture and KVK professionals as mostly they have less direct interaction with the farmers. They always contact the farmers through intermediaries like farmer's club, NGO etc.

\section{Private companies}

Private companies like Seed Company, Fertilizer Company, agro- chemicals, processing industry etc. have strong linkage with input dealers and NGO as the companies can sale their products to them in bulk through their distributors across the region. Farmer's demand for inputs met by the private companies via input dealers and NGO. Private companies like manufacturer of farm power machineries, pumps, motors have some link with State Agriculture University for providing machineries to the farmers of the adopted village and university's project sites. 


\section{Non-Government Organization (NGO)}

Women staffs associated with the NonGovernment Organization which acts as the service provider in this system. NGO provides inputs to the farmers after collecting it from various private companies, input dealers. So, NGO has a strong linkage with input suppliers and some of the local input dealers are also the members of the NGO. NGO gets financial assistance from NABARD and other banks located in the study area for creating their own resources and assets like land, hatchery, school building, training centre, vehicle etc. They also take financial helps for organizing Farmer's fair, awareness programmes and running the NGO efficiently. The NGO plays a key role to form the farmers' club, women self-help groups and gives continuous guidance to them. NGO also shares a strong linkage with Assistant Director of Agriculture to make state extension service easily accessible to the farm women. In case of conducting training programmes for the farmers NGO invites experts from the KVK and State Agriculture University. NGO and gram panchayat always act as the partners in various projects implemented by the Block Development Office of the study area. Most of the time NGO and gram panchayat officials considers themselves as the competitors to each other and there is always some conflicts regarding their way of carrying out developmental programmes in the study area. These types of poor linkages often negatively contribute to the capacity of the agricultural innovation system.

\section{Input dealers}

Input dealers have strong association with the farm women, private companies, farmers' club and NGO. Input dealers have direct and regular contact with these actors and have medium linkage with the financial institutions in case of availing credits for buying inputs, machineries and their maintenance.

\section{Financial Institutions}

Financial institutions like banks, cooperative societies have a very good and strong linkage with the NGO. In banks women are at the position of manager, agricultural field officer who are providing KCC loan to the farm women. Women are also serving as the business correspondence provides consultancy to generate appropriate documents to avail the loan from bank. They also help women SHG members in case of getting loan and managing their accounts in an efficient manner. But they have medium linkage with women farmers, input dealers, gram panchayat officials as there are some problems or misunderstandings between the credit agents and the other stakeholders regarding availing loans and repayment of loan and other banking operations. Various actors stated that difficulty in getting loan at the right time is one of the major constraints for adopting agricultural innovations.

\section{Farmers' club}

Farmers' club along with NGO is sharing the responsibility to conduct their activities properly and linked with input dealers for supplying inputs to the women farmers. Women members of the farmers' club provide training to women SHGs, give consultancy and guidance to manage the SHGs effectively and motivate farm women to adopt modern agricultural practices. Farmers' club also establishes strong communication with ADA and KPS as it acts as the bridging institution for the women farmers and sate extension professionals. It has medium level of linkage with Krishi Vigyan Kendra and Comprehensive Area Development Corporation (CADC). As farmers' club has no direct contact with these organizations, it receives information from these institutions through NGO. 


\section{Krishi Vigyan Kendra (KVK)}

KVK is the integral part of State Agriculture University (SAU). Director of Extension of the state agriculture university conducts its extension related activities through the KVK. Krishi Vigyan Kendra keeps contact with the NGO for selecting farmers and making arrangements of training programmes, exposure visit or field day at the study area. Some of the farmers' club members and farmers use SMS service for getting information from KVK. Women farmers have some sort of interaction with KVK professionals during various training programmes. KVK has no direct linkage with Assistant Director of Agriculture.

\section{Assistant Director of Agriculture (ADA)}

Assistant Director of Agriculture is maintaining a direct contact with the NGO and farmers' club in case of disseminating agricultural information to the farming community. NGO and farmers' club are the missing link between farmers and state extension professionals in case of conducting any sort of agricultural development programmes in the study area. Assistant Director of Agriculturehas very limited face to face interaction with the women farmers. In case of implementing project activities related to agricultural research and development or testing and validating of new technology ADA seeks cooperation from the experts of the State Agriculture University.

\section{State Agriculture University (SAU)}

State Agriculture University mostly maintains direct contact with NGO for carrying out various programmes and projects in the study area. State Agriculture University has good link with Krishi Vigyan Kendra and other organizations like Assistant Director of Agriculture regarding the implementations of various state government projects, preparing action plan for the district or block. But it has poor linkage with ultimate women users of agricultural innovations.

\section{Gram panchayat office}

Gram panchayat office is a political institution at village level which is primarily following the instruction of the Block Development Office and act accordingly in case of implementing on going development programmes in the village. Gram panchayat office mostly looks after the activities like road construction, land levelling, excavation of pond etc. under MGNREG programme that are performed by the women farmers and labourers. Besides this, gram panchayat office is also associated with financial institution regarding financial matters.

\section{Comprehensive Area Development Corporation (CADC)}

Department of horticulture under CADC also an active partner of this women led innovation system. It has strong linkage with the NGO in case of involving women SHGs in a orchard model project where CADC provides seedlings of papaya, lemon and guava to the women SHG members to make women self- reliant.

\section{Actor linkage matrix}

Actor linkage matrix shows that each actor has some stake in various domains of the innovation system such as research, extension, input supply, credit support and enabling environment etc. The matrix also reveals that in the given innovation system researchers are mainly engage in development of hybrid varieties, breeds etc. which is primarily carried out by the scientists of State Agricultural University or the Department of Agriculture at block level jointly with the NGO working in the study area. KVK, NGO, farmer's club are the extension organizations that are mainly involved in dissemination of 
information, trainings etc. NGO also serves as the link between farmers and other actors in the system. Extension services of the government organizations reached to the farmers either directly or indirectly through the NGO. Input dealers in this system mainly linked with farmers, farmer's club, private companies in distribution, marketing and selling of different agricultural inputs.

In conclusion, the identified actors of women led agricultural innovation system and their activities are showing a clear penchant towards the diversified characteristics and connotations of the stakeholders for enhancing the capacity of the existing agricultural innovation system and also it creates the space to incorporate several other actors present in the local situation for solving the problems associated with and getting the collective benefit from the local agricultural innovation system. It may be also recommended that there is a need of a welldeveloped structural platform to discuss the problem and promote the solution among the actors responsible for building the capacity of agricultural innovation system. This structured platform will bear the responsibility of capacity enhancement through accommodating all the actors in agricultural innovation system with a collective decision and may be named as "Local Innovation Platform" or "Capacity Enhancement Forum". transformation in the delivery of agricultural extension services: Implication for research-extension-farmer linkage' Outlook on Agriculture, 36 (1): 35-39.

Agbamu, J. U. (2000). Agricultural researchextension linkage systems: an international perspective. Network Paper No. 106. Agricultural Research and Extension Network (AgREN).

Biggs, S and Matsaert, H. (2004). Methodological framework for analyzing the agricultural science technology and innovation (ASTI) systems in ACP Countries. CTA/UNUINTECH/KIT. Www.2005_CTA UNUINTECHKIT_Revised_ASTI_method ology

Klerkx, L.,Hall, A. and Leeuwis, C. (2009) 'Strengthening agricultural innovation capacity: are innovation brokers the answer?,' International Journal Agricultural Resources, Governance and Ecology, 8 (5/6): 409- 438.

Leeuwis, C. Van den Ban, A. (2004), Communication for Rural Innovation, rethinking agricultural extension (with Contributions of Anne van den Ban) Blackwell science, Oxford, UK.

Mohammad, A., J. Gupta, R. S. Kumar, and S. Subash. (2012). Linkage Pattern Among Actors of Milk Production Innovation System in Coastal Saline Soil Zone of West Bengal (India).\| Journal of Global Communication 5 (3): 39-43.

Spielman, D. J. (2006). A critique of innovation systems perspectives on agricultural research in developing countries. Innovation Strategy Today 2(1): 25-38.

\section{References}

Aflakpui, G. (2007) 'Present outlook and

\section{How to cite this article:}

Rema Das. 2020. Detection and Mapping of Actor Linkages in a Woman led Agricultural Innovation System (AIS). Int.J.Curr.Microbiol.App.Sci. 9(07): 2650-2659.

doi: https://doi.org/10.20546/ijcmas.2020.907.311 